\title{
The Effect of Family Caregiver Support used Three Dimension Magnetic Diabetic Food to Improve Diet Management
}

\author{
Pipit Festi Wiliyanarti $^{1 \star}$, Robiatul Adewiyah ${ }^{1}$, Gita Marini ${ }^{2}$, Israfil Israfil $\left.\right|^{3}$ \\ ${ }^{1}$ Departement of Nursing Community and Family, Faculty of Health Science, Universitas Muhammadiyah Surabaya, Surabaya, \\ Indonesia; ${ }^{2}$ Departement of Nursing Child, Faculty of Health Science, Universitas Muhammadiyah Surabaya, Surabaya, \\ Indonesia; ${ }^{3}$ Departement of Public Health, Nursing Poltekes Kemenkes Kupang, Kupang, Indonesia
}

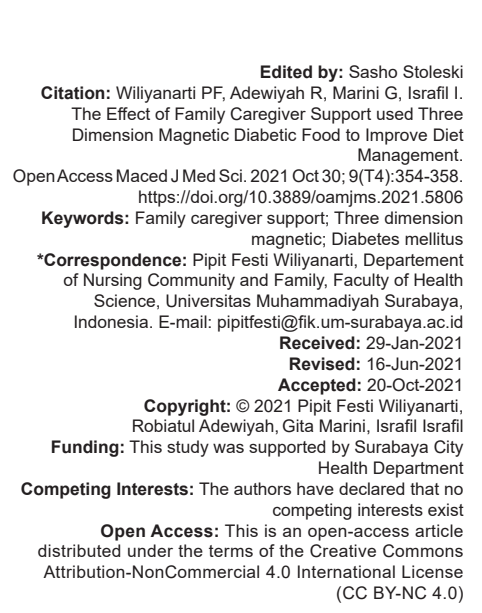

\section{Introduction}

Getting older, the elderly will have physiological and psychological deterioration that can cause various diseases [1]. Degenerative diseases in the elderly that occur as a result of decreased physiological function are diabetes and hypertension. Diabetes mellitus (DM) was a chronic and progressive metabolic disorder. Advances in technology can lead to lifestyle changes such as instant dietary changes, it can lead to an increase in the occurrence of DM [2].

The prevalence of DM sufferers from year to year tends to increase. Based on data from the International Diabetes Federation, the number of people with DM in the world in 2018 was 546 million people and was expected to increase in 2030 to 552 million people [3]. Data from the Indonesian Endocrine Association, Indonesia will have an increase in the number of people with diabetes from 7.0 million to 12.0 million people in 2030 [4]. The prevalence of type 2 DM in Indonesia reaches almost $80 \%$. According to the World Health Organization (WHO), the number of people with DM in Indonesia will increase to 21.3 million people in 2030 and was in the fourth position after the United States, China, and India [5].

Riskesdas explains that the number of diabetes sufferers was 13 million people [6]. The number of diabetes patients in East Java was $2.5 \%$ of the $28,885,895$ residents of East Java who are over 14 years old. In 2018, the regions with high diabetes rates in East Java were Surabaya, which was in the largest order with 15,444 cases per year, followed by Bangkalan, Madura 5,388 cases, Malang 7,534 cases, and Lamongan 4,138 cases. Management of DM, the main thing that was done was meal planning or dietary patterns for patients. But often DM sufferers, especially the elderly, do not comply with the dietary patterns that have been implemented by health workers. According to previous study patient compliance in carrying out their diet was only done when the patient's sugar level has increased, whereas if the blood sugar level has decreased and the patient feels his condition has improved, the patient was no longer on the diet [7]. Another study found that the average DM sufferer 
was less aware of the DM diet [2]. The results of the preliminary study showed that in the work area of the Primary Health Care in Surabaya, data on visits to the Primary Health Care were obtained from March and April 2019 , there were $45 \%$ of all outpatients with DM in the elderly.

The correct and proper diet requires patient compliance and active participation and assistance of family and community. Proper and correct diet planning can get better metabolic control and blood sugar can also be controlled [8], [9]. Elderly people with DM experience less knowledge about the DM diet, especially about the types of food that can and should not be consumed, the right and appropriate eating schedule, and the number of calories needed [10]. Improper or inappropriate diet processing will have an impact on the level of glucose instability in the patient's body [9], [11].

Elderly with diabetes can experience cognitive decline, this was an obstacle in diabetes management. The impact of cognitive decline in the elderly with diabetes was that the health status of the elderly with DM will decrease, productivity decreases. In line with the previous study, it was stated that the presence of chronic diseases suffered by the elderly will result in decreased quality of life [1]. Therefore, it requires parenting support from the elderly group. Family caregiver support helps the elderly with diabetes in its management, especially inpatient meal planning. Family caregiver support was very important because this diabetes care plan was complex and requires a caregiver who can be responsible for some diabetes management, especially in the diet [12].

Family members are involved in support or caregiver support in diabetes management including meal/diet planning [13]. Families can provide the above support, which acts as caregiver support, requiring health education from medical personnel to increase knowledge from caregivers about the dietary patterns of DM sufferers. A study found that food model media and flip charts to conduct health education for DM patient diet patterns, but the results showed that using the food model media was more effective than flip charts [14]. The media that will be used in this research was a miniature three dimension (3D) magnetic diabetic food, which will describe the meal planning/diet of diabetics, this media will contain schedule, amount, and type [9], [15]. Family caregiver support uses this 3D magnetic diabetic food miniature media as an alternative to help patients more adhere to the meal plan/diet set by medical personnel.

The purpose of this study was to analyze the effect of family caregiver support using a miniature 3D magnetic diabetic food on was to the dietary patterns of DM patients in the elderly.

\section{Methods}

The research design used a pre-experimental design with a static group comparison design approach. The study population was 90 families with DM using a probability sampling technique, random sampling, then divided into two groups, the treatment group, and the control group respectively 36 elderly and their families, according to predetermined inclusion and exclusion criteria. Inclusion Criteria: (1) Families with elderly people have DM. (2) Family members who accompany the elderly at all times (3) Elderly with DM aged 55-70 years living in Surabaya. Exclusion Criteria: (1) Family and elderly DM patients who refuse to be respondents (2) Elderly DM patients who are in a sick condition that interferes with the study (3) DM patients who have complications, so use type IV and V DM diets.

This research was conducted on July 31, 2019,-August 31, 2019. Independent variable family caregiver support with 3D magnet diabetic food miniature media, the dependent variable of DM dietary compliance. The instruments used were the 24-h food recall form and the Morisky Medication was Scale-8 Questionnaire Sheet.

The research was carried out for 1 month in the treatment group starting with a questionnaire and then providing assistance and health education using magnetic miniature food as a reminder, family guidelines in regulating the patient's daily diet. Researchers provided assistance and health education to families by providing guidelines (dietary schedule according to the rules, type of food, amount of food for 1 month the patient was observed dietary compliance. Whereas in the control group was only given DM diet guideline leaflets without any assistance, then the observation was carried out after 1 month. The analysis used to determine the differences in dietary was in the treatment group used the Wilcoxon Signed rank test statistical test with a significance degree $<0.05$, while the analysis to determine the differences in was to the control group and the treatment group used the ManWhitney test with a degree of significance $<0.05 .3$.

\section{Results and Discussion}

Diet compliance with DM patients before given family caregiver support using 3D magnet diabetic food miniature in Tambak Wedi Surabaya. Look at the following table.

Based on Table 1 above, the results of this study indicate that the was to the dietary pattern of DM sufferers before being given family caregiver support using a miniature $3 D$ magnetic food diabetic respondents with low compliance. 
Table 1: Diet compliance with DM patients in the treatment group before given family caregiver support using 3D magnet diabetic food miniature in Surabaya in August 2017

\begin{tabular}{ll}
\hline Diet compliance & $\begin{array}{l}\text { Diet compliance with DM patients before family caregiver support } \\
\text { (pre-test) }\end{array}$ \\
\cline { 2 - 2 } & $\mathrm{n}(\%)$ \\
\hline High & - \\
Medium & $15(41.7)$ \\
Low & $21(58.3)$ \\
Total & $36(100)$ \\
\hline DM: Diabetes mellitus, 3D: Three dimension.
\end{tabular}

Education was an important factor for someone who can understand the disease they suffer, can carry out self-care, including understanding the management of food consumed to control blood sugar so that it remains stable, and DM sufferers continue to experience an optimal quality of life that people who have low education are very vulnerable to experiencing health problems [16]. Factors that influence someone to do non-compliance are caused by a person's lack of understanding of the instructions/management of the disease, which he does not understand, secondly, the lack of interaction between health professionals and patients [17]. Third, the lack of family attention to patients in helping determine the program to be implemented. Beliefs, attitudes, and personality are the last point. Another cause of was to the DM diet was the lack of interaction between health workers and respondents, this can be seen from how elderly DM sufferers who come to the elderly are only a small proportion of existing DM sufferers.

Based on Table 2 shows that the results of the study of was to the dietary pattern of DM sufferers after being given family caregiver support using a miniature 3D diabetic food magnet, moderate compliance, namely as many as 22 respondents $(61.1 \%)$, High was as many as 14 respondents $(38.9 \%)$ out of 36 respondents and there were no respondents who had low compliance. Meanwhile, in the control group that was only given leaflets to their families, most of them had low compliance, as many as 21 respondents, with a total of $58.7 \%$.

Table 2: Compliance with DM patients with dietary patterns after providing family caregiver support using 3D magnet diabetic food miniature in Surabaya in August 2017

\begin{tabular}{lll}
\hline Diet compliance & $\begin{array}{l}\text { Compliance with dietary patterns of DM } \\
\text { patients with family caregiver support } \\
\text { (post-test) }\end{array}$ \\
\cline { 2 - 3 } & $\begin{array}{ll}\text { Intervention } \\
\mathrm{n}(\%)\end{array}$ & $\frac{\text { Control }}{\mathrm{n}(\%)}$ \\
\hline High & $14(38.9)$ & - \\
Medium & $22(61.1)$ & $21(41.7)$ \\
Low & - & $21(58.3)$ \\
Total & $36(100)$ & $36(100)$ \\
\hline$\rho=0.000<\alpha=0.05$. (Wilcoxon signed ranks test). $\rho=0.000<\alpha=0.05$ (Man Whitney). \\
DM: Diabetes mellitus, 3D: Three dimension.
\end{tabular}

Based on the results of the study, there were differences in patient was after being given assistance and health education using diabetic miniature food in the treatment and control groups. The results showed that the group that did not use 3D media had lower was than the treated group. Dietary patterns in DM patients have increased seen from the impact felt by respondents after receiving treatment in the form of Family Caregiver
Support using 3D magnetic diabetic food miniature, it was found that most families who served as caregivers felt they could understand the DM diet pattern obtained from miniature 3D diabetic food. magnet. Therefore, the family said that there was an increase in knowledge in carrying out their duties to provide a diet or diet and education for people with diabetes. While the impact felt by DM sufferers themselves feel better because they get full support from their family.

Providing health education with simple materials and appropriate methods to patients and families will increase family knowledge in managing dietary patterns [18]. This was in line with Lewis (2011) who stated that the support provided by caregivers was important in helping patients heal physically, psychosocial, and spiritually [19]. The purpose of holding health education was different between sufferers and caregivers. Patients and caregivers have different needs and teachings. The main priority for elderly DM sufferers for dietary regulation needs to be teaching about the food consumed. Meanwhile, the caregiver must focus more on the procedures for eating patterns or diets as a whole, starting from the type, quantity, and schedule of the food they consume.

The role of the caregiver itself varies, it can be seen that the role was different according to the status and relationship with the care recipient. A caregiver will experience a significant change in role when a caregiver was a parent, husband or wife, children, siblings [20], [21]. Family in providing support for DM sufferers has four dimensions, namely emotional support, reward support, instrumental support, and information support [20], [22].

Pramukti in his research explained that learning media in the form of a food model was more effective for health education in DM patients [22]. The food model props have more appeal in attracting interest from respondents because the media was real or real objects. As stated by Notoatmodjo, the process of health education using original objects or copies of the original objects has the highest intensity for perceiving educational or teaching materials [16].

Patient was to the principles of nutrition and meal planning was one of the obstacles in diabetes patients. Many diabetics feel tormented about the type and amount of food recommended. Dietary was to DM sufferers can increase if they get maximum family support, starting from the task of emotional, physical, and social support [23]. Patients and caregivers need health education and different treatment. Giving treatment to the caregiver can change the knowledge of the caregiver to be more improved because of the 3D Magnet Diabetic Food media because the media can remind and perceive the caregiver's duties. So that the caregiver can provide care to DM sufferers properly.

Results of difference analysis based on Table 2 shows the results of the Wilcoxon Signed rank test statistical test to determine the compliance of dietary 
patterns before and after being given family caregiver support intervention using the 3D magnetic diabetic food miniature shows the results with significance $\rho=0.000$ with the degree of significance used was $\alpha<0.05$, meaning that there was an effect of family caregiver support using 3D magnetic diabetic food miniature on changes in compliance with DM sufferers in Surabaya. While the results of different tests in the control group and the treatment group showed $\rho=0.000$, which means there was a difference in dietary was in the group that was given support in the form of food diabetic media compared to the dietary compliance of patients who were only given leaflets. Miniature food diabetic in the form of sticky images using magnetic which can be a reminder for patients and their families in carrying out their dietary patterns. Foods that should be avoided include high glucose content such as sweet drinks and sweetbreads that are difficult for DM patients to avoid [9], [24].

In undergoing diet therapy, support in the family was needed so that patients feel comfortable and at ease in undergoing the DM diet. Furthermore, DM patients are obedient in carrying out orders, obeying rules, and discipline in carrying out a predetermined diet program, so that complications can be controlled [9]. This was in line with the research of students, Wibowo et al., 2018 which states that psycho-educating caregivers in families can improve the care for Type II DM patients.

Based on the results of research and several theories, it can be assumed that respondents who do not experience an increase in the level of was to the diet of DM sufferers are due to the higher family age being caregivers than other respondents. Families will experience a significant change in their role in their family environment when they become caregivers, as did the respondents in this study. Respondents who did not experience an increase because the family who served as caregivers was the husband of the respondent. So that the emotional support given was better for female caregivers. Respondents who did not experience change, because the caregiver was less active in the management of family caregiver support at the time of the study. So that the caregiver's knowledge about the management of the DM diet was lacking. The management of DM was known as the four main pillars of management, namely: counseling, meal planning, physical exercise, and hypoglycemic drugs. Nutritional therapy was a major component of successful diabetes management [14].

\section{Conclusion and Suggestion}

Based on the research results it can be concluded that: there was an effect of family caregiver support using 3D magnetic diabetic food miniature on the compliance of DM sufferers in the elderly in Surabaya.

Family Caregiver Support was expected to be used as a learning method in providing nursing care to DM patients, especially in the elderly. Health services are expected to further improve educational programs regarding dietary modification for DM sufferers and Family Caregiver Support can be used as a reference in family education programs to increase family independence in caring for DM patients in the elderly.

\section{References}

1. Wiliyanarti PF. Lanjut Usia Perpektif dan Masalah. Surabaya. UMSurabaya Press; 2018

2. Raharjo AS. Hubungan Tingkat Pengetahuan san Sikap Dengan Kepatuhan Diet Diabetes Melitus pada Penderita Diabetes Melitus si Desa Gonilan. Universitas Muhammadiyah Surabakarta; 2015

3. Internasional Diabetes Federation; 2016. Available from: http://www.tanggal10setember2018dariwikipedia.org/wiki/ internasionaldiabetes-federation. [Last accessed on 2021 Jun 10].

4. Perkeni. Kriteria Diagnostik DM Tipe 2. Konsensus Pengelolaan dan Pencegahan Diabetes Melitus Tipe 2 di Indonesia; 2015. p. 11-4.

5. Kementrian Kesehatan Republik Indonesia. Infodatin Pusat Data dan Informasi Kementrian Kesehatan Republik Indonesia Diabetes. Jakarta; Kementrian Kesehatan Republik Indonesia; 2014.

6. Riset Kesehatan Dasar (Riskesdas). Badan Penelitian dan Pengembangan Kesehatan.

7. Gustina HS. Faktor-Faktor Yang Berhubungan Dengan Kepatuhan Diet Diabetes Mellitus Pada Pasien DM. Vol. 2. Jur Keperawatan Poltekkes Kemenkes Jakarta III; 2014.

8. Abdillah DA. Pengaruh Pendampingan Terhadap Kepatuhan Diet pada Penderita Diabetes Melitus Tipe 2 di Wilayah Puskesmas Banyuar Surakarta. Stikes Kusuma Husada, Surakarta; 2016.

9. Wiliyanari PF. Nutrition and Diet Textbook; 2018.

10. Hartiningsih. Pengaruh Pendidikan Kesehatan dengan Media Audiovisual dan Media Booklet Terhadap Sikap Caregiver dalam Mencegah Penularan Tuberkulosis pada Anggota Keluarga. J Perspekt Pendidik. 2018;12(1):12

11. Retnaningtyas Novitasari. Hubungan Antara Pengetahuan Dan Sikap Dengan Kepatuhan Diit Diabetes Mellitus (DM) Pada Lanjut Usia (Lansia) Di Kelurahan Gayam Kecamatan Sukoharjo. Universitas Muhammadiyah Surakarta; 2015.

12. Feil DG, Pearman A, Victor T, Harwood D, Weinreb J, Kahle K et al. The role of cognitive impairment and caregiver support in diabetes management of older outpatients. Int J Psychiatry Med. 2009;39(2):199-214.

13. Awadalla AW, Ohaeri JU, Al-Awadi SA, Tawfiq AM. Diabetes mellitus patients' family caregivers' subjective quality of life. J Natl Med Assoc. 2006;98(5):727-36.

PMid: 16749648

14. Pramukti AL, Kristiyawati SP, Purnomo SE. Efektifitas Peraga Food Model Dan Flip Chart Dalam Pendidikan Kesehatan Pasien Diabetes Mellitus Type II Di RSUD Tugurejo. Vo.I. 2. Karya IIm STIKES Telogorejo; 2013.

15. Wulandari R. Buletin TUMBUH (Teduh Untuk Sembuh): Pola Makan 3J bagi Penderita Diabetes Melitus. Media Komunikasi 
RS Dr Oen Surakarta; 2013.

16. Notoatmodjo. Pendidikan Dan Perilaku Kesehatan. Jakarta: Rineka Cipta; 2012.

17. Niven N. Psikologi Kesehatan. $2^{\text {nd }}$ ed. Jakarta: EGC; 2014.

18. Harwadi H, Ibrahim K, Hayaty H. Pengaruh Pendidikan Kesehatan Terhadap Kepatuhan Diet Pada Pasien Dm Tipe2 Di Irna Non Bedah Penyakit. J IImu-IImu Kesehat Bhakti Husada Kuningan 2015;4(2):5.

19. Lewis SL, Dirksen SR, Heitkemper MM, Bucher L. MedicalSurgical Nursing: Assessment and Management of Clinical Problems. $9^{\text {th }}$ ed. United State America: Elsevier Mosby; 2016.

20. Friedman MM, Bowden VR, Jones EG. Family Nursing Textbook: Research, Theory, and Practice. Jakarta: EGC; 2010.
21. Friedman MM, Bowden VR, Jones EG. Family Nursing Research, Theory and Practice. $5^{\text {th }}$ ed. New Jersey: Prentice Hall; 2003.

22. Given BA, Given CW, Sherwood PR. Family and caregiver needs over the course of the cancer trajectory. Support Onkol. 2012;10(2):57-64.

23. Nurhidayati. Hubungan Dukungan Keluarga Dengan Kepatuhan Diet Pada Pasien Diabetes Melitus Rawat Jalan Di RS PKU Muhammmadiyah Yogyakarta. Universitas Muhammadiyah Yogyakarta; 2011.

24. Soegondo S, Pradana S, Imam S. Penatalaksanaan Diabetes. $2^{\text {nd }}$ ed. Jakarta: Badan Penerbit FKUI; 2015. 